IJIET, e-ISSN 2548-8430, p-ISSN 2548-8422, Vol. 2, No. 2, July 2018

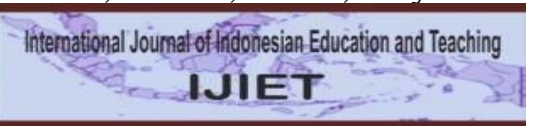

International Journal of Indonesian Education and Teaching

http://e-journal.usd.ac.id/index.php/IJIET

Sanata Dharma University, Yogyakarta, Indonesia

\title{
THE EFFECTIVENESS OF CAREER GUIDANCE PROGRAM FOR PSYCHOLOGY STUDENTS
}

\author{
Monika \\ Tarumanagara University Jakarta \\ monika@fpsi.untar.ac.id \\ https://doi.org/10.24071/ijiet.v2i2.1564 \\ received 23 November 2017; revised 15 June 2018; accepted 15 July 2018
}

\begin{abstract}
Making a career decision is a complex process. Although some people make decision easily, others face difficulties in making their career decision. Therefore, identifying their difficulties in career decision-making process is an essential step to provide students' needs in their career planning. According to Gati, Krausz, and Osipow (1996), the proposed taxonomy of career decision-making difficulties was developed through interaction and sequential interplay between theoretical considerations and empirical testing. Specifically, in the proposed taxonomy the difficulties are divided into three major categories. The first major category isLack of Readiness. Then the second and the third major categories are Lack of Information and Inconsistent Information. The participants of this study were 95 psychology students divided in two groups (experimental and control groups). The aim of this study is to describe career decision-making in psychology studentsand to determine the difference of career decision-making difficulties in students with different semesters. The result of this study shows that The Career Guidance Program is effective for decreasing difficulties of career decision-making (lack of information, inconsistent information, and total difficulty), but less effective to decrease the lack of readiness.
\end{abstract}

Keywords: career decision-making, career guidance, psychology students

\section{Introduction}

Students are learners who are registered and studied at certain universities (Government Regulation No.30 of 1990). Based on statistical data from the Directorate General of Higher Education (2015), currently there are 3,612,286 active students who are studying Strata 1 or the undergraduate education, while in Jakarta there are 501,191 active students, with an age range between 18-30 years old. According to Arnett (in Lemme, 2006) the age of 18-25 years old is a new stage of life. The transition period between adolescence and early adulthood is the length of time an individual gains the freedom to make long-term decisions. Decision making here includes career-related decision-making. Career-related decisionmaking is complex. Individuals may have difficulty in doing so. The difficulties individuals experience during the career decision-making process can 
be classified into two categories, the lack of information and information inconsistencies. The lack of information includes about their own selves, work, and how to obtain the information. While the inconsistency of unreliable information includes internal conflicts, and external conflicts (Gati, Kraus, \& Osipow, 1996)

In students who have entered a particular department or course of study, career choices should have been limited to the study field. Nevertheless, it is oftenfound that final-year students find it difficult to make career decisions because there are lack of information about the career that they can take after graduating from university or because of there are so many career opportunities that can be taken. The examples here are the psychology students. Psychological science itself is divided into various areas of study, such as Educational Psychology, Clinical Psychology, Developmental Psychology, Industrial and Organizational Psychology, Forensic Psychology, and so forth. Each field of study has different career opportunities that require different tasks and competences.

Psychology Faculty of X University, conducting Career Guidance Course which aims to help students plan their career. The lecturer in this course creates a career guidance program, which contains a series of activities that can help students from career planning to career decision making. Nevertheless, the program has never been evaluated for its effectiveness on students' career decision-making abilities. Therefore, this study aims to determine the process of career decisionmaking on students, as well as evaluate career guidance program on students. Furthermore, this program is expected to be a model of career guidance programs in other education levels, such as high school or vocational high school.

\section{Career Decision-Making}

According to Gati, Krausz, and Osipow (1996), making a career decision is a complex matter. The career decision-making process has the same characteristics as in other decision-making processes, meaning that the process involves an individual choosing what he or she feels most appropriate from career possibilities based on comparison and evaluation of career alternatives, taking into account the reality that the comparison and evaluation process is influenced by both the characteristics of the educational/professional program and the individualcharacter. In addition, the career decision-making process has several distinctive features, such as, an individual makes decisions of various career possibilities, for every career alternative there is abundant information available, and the fact that various aspects of the profession should be considered (e.g. duration of the educational process, independence in work etc.).

In career decision-making, the individual's ability impacts on whether the individual is accepted for the training or work he or she wants, while the ability of the individual also plays an important role in career decision-making (Gottfredson, 1986, in Gati, 2013). Individual capability measurement is often done as a consideration during the counseling process (Gottfredson, 2005; Osipow \& Fitzgerald, 1996, in Gati, 2013). Measurement tools with paper and pencil, like intelligence test, only includes several capabilities. Individuals should use selfestimation in making consideration in career decision-making. Prediger (1999, in 
Gati 2013) states specific domains on self estimation capability are more relevant in career selection than in general ability (intelligence).

Campbell and Hefferman (in Gati, 2009) classify difficulties in career decisionmaking in several categories and sub categories. The proposed taxonomydivides the difficulties of career decision-making into three major categories: 1) lack of readiness, 2) lack of information, and 3) inconsistent information. Taxonomy of career decision-making difficulties illustrates that there are two parts to the difficulty of career decision-making, based on the timing of the emergence of the difficulty. First, difficulties arise before starting the careerdecision-making process, and the second, difficulties that arise during the career decision-making process.

In difficulties before starting the career decision-making process there are categories of lack of readiness, including: lack of motivation, general indecisiveness, and dysfunctional beliefs. While on the difficulties facing individuals during the career decision-making process, there are two main categories. Category concerning lack of information, including: lack of information about the career decision-making process, lack of information about the individual's own self, lack of information about work, and lack of information on how to obtain information. The next category deals with inconsistent information, including: unreliable information, internal conflicts, and externalconflicts.

\section{Psychology Students}

According to Sarwono (cited in "Definition of Student's Definition According to Experts, 2012), the student is every individual who is officially registered to attend college studies in university with the age limit of about 18-30 years old. Furthermore, Arnett (cited by Lemme, 2008) states that in that age period (which age 18-25) is a transition period from adolescence to early adulthood where an individual has the freedom to take long-term decisions. In this period Piaget (in Santrock, 2011) in his cognitive development theory also classified this early adulthood in the fourth period, formal operations in which the individual has the capacity to think systematically for abstract and hypothetic information.

Furthermore, psychology is a discipline of science about scientific research on mental behavior. It not only explains what we do and how we behave, but also examine the flow of thought and reason behind our actions. Ranging from perceptual thinking, cognitive recognition, and interpersonal relationships, psychological theories and information are often used to solve problems in a wide range of human activities. Some psychology studies include: developmental psychology, social psychology, personality psychology, educational psychology, industrial and organizational psychology, educational psychology, and clinical psychology.

Developmental psychology is a field of psychology that examines human development and the factors that shape a person's behavior from birth to elderly. Developmental psychology is closely related to social psychology, since most developments occur in the context of social interaction. Developmental psychology also closely related to the personality psychology, because the development of individuals can form a distinctive personality of the individual. 
Furthermore, social psychology has 3 scopes, namely the study of social influences on individual processes, such as the study of perception, learning process motivation, attribution; the study of group processes, such as language, social attitudes, imitative behavior and so on. Then the personality psychology is the field of psychology that studies the behavior of humans in adjusting to the environment, personality psychology is closely related to developmental psychology and social psychology, because the personality is the result of individual development since childhood and how the individual itself doing social interaction with the environment. The next study is educational psychology. This field of study seeks to create a supportive situation for students in developing academic, socialization and emotional skills which aims to form the mindset ofthe students. Furthermore, industrial and organizational psychology focuses on developing, evaluating and predicting the performance of a work done by the individual. The field of clinical psychology is the field of psychology and also the application of psychology in understanding, preventing and restoring the individual psychological state to the normal threshold.

\section{Method}

This research used a research design in the form of two groups, namely a pretest-posttest design. There was one experimental group that received treatment and one control group that was not treated. Measurements were performed twicein each group, which are before treatment (pretest) and after treatment (posttest). The treatment in this research is a career guidance program.

Participants in this research are students of $6^{\text {th }}$ semester of Faculty of Psychology at private university in Jakarta. Overall, the number of participants in the study was 95 participants. The number of participants in the experimental group was 56 participants $(58.9 \%)$, while 39 other participants $(41.1 \%)$ were included in the control group. The sampling technique in this research is purposive sampling.

Measurement in this study is using Career Decision-making Difficulties Questionnaire (CDDQ). This CDDQ measuring instrument was developed by Gati, et al. through his research entitled "A taxonomy of difficulties in career decision making" (1996). Furthermore, in 2016, Imda (2016) translates this CDDQ measuring instrument in his thesis research entitled "Pelatihan Model PIC dalam Mereduksi Kesulitan Pengambilan Keputusan Karir pada Remaja Panti Asuhan”. (In English: "PIC Training Model in Reducing Career Decision-Making Difficulties in Teen Orphans"; PIC stands for Prescreening, In-depth Exploration, Choice).

\section{Findings and Discussion Description of Intervention}

The intervention process consists of eight meeting session. In general, the study participants looked enthusiastic in following each intervention session. Their enthusiasm appears in the form of questions asked, as well as the willingness and passion shown in each process of the activities undertaken. The eight sessions include the following: 1) The first session is an introduction, an 
explanation of the intervention, mapping the participants' career picture through open-ended questions, and pretest, 2) The second session is the search for participants' potential and interests based on Donald Super and Holland's career theory, 3) The third session is a reflection of the advantages and weaknesses of the participants, as well as the search for the value of each work alternatives that the participants are interested in, 4) The fourth session is to create a list of career alternative considerations that are divided on the supportive considerations and the deliberate considerations, 5) The fifth session is the career decision-making based on the considerations that have been made, 6) The sixth session is the career planning in the next 5-10 years, 7) The seventh session is a presentation in front of the facilitator and other participants about the career exploration process that has been done by students, and 8) The eighth session is posttest and evaluation of the intervention process that has been done.

\section{Description of Variable Research (Pre-Post)}

In the experimental and control groups, overall or per dimension, the difficulty level of career decision-making during the pretest and posttest held by most participants was moderate or intermediate. This can be seen from the mean scores in the table below. Participants with a mean score of less than 3.329 were classified as participants who had difficulty making career decisions at a low level, mean scores 3.330 to 6.329 were classified as moderate, and mean scores over 6.330 were ranked as high.

Table 1. Difficulty level of Career Decision-Making in Experimental Group

\begin{tabular}{lcccccc}
\hline & \multicolumn{3}{c}{ Pretest } & \multicolumn{3}{c}{ Posttest } \\
\cline { 2 - 7 } & Low & Moderate & High & Low & Moderate & High \\
\hline LoR & 5 & 47 & 4 & 9 & 43 & 4 \\
LoI & 13 & 31 & 12 & 27 & 24 & 5 \\
II & 15 & 37 & 4 & 28 & 25 & 3 \\
Total & 10 & 42 & 4 & 20 & 32 & 4 \\
\hline
\end{tabular}

Note: LoR =Lack of Readiness; LoI = Lack of Information; II = Inconsistent Information; Total $=$ The Total of Difficulty Level of Career Decision-Making

Table 2. Difficulty level of Career Decision-Making in Control Group

\begin{tabular}{lccrccr}
\hline & \multicolumn{3}{c}{ Pretest } & \multicolumn{4}{c}{ Posttest } \\
\cline { 2 - 7 } & Low & Moderate & High & Low & Moderate & High \\
\hline LoR & 5 & 32 & 2 & 6 & 32 & 1 \\
LoI & 13 & 24 & 2 & 10 & 24 & 5 \\
II & 16 & 22 & 1 & 12 & 26 & 1 \\
Total & 11 & 27 & 1 & 10 & 27 & 2 \\
\hline
\end{tabular}

Note: LoR =Lack of Readiness; LoI = Lack of Information; II = Inconsistent Information; Total $=$ The Total of Difficulty Level of Career Decision-Making

Roughly speaking, it can be said that the difficulty level of career decisionmaking in the experimental group decreased after the experiment or manipulation was done. Major decreases occur particularly in the dimensions of lack of information (mean differences $(\mathrm{MD})=1.06)$, inconsistent information $(\mathrm{MD}=0.85)$, and total career decision-making difficulties $(\mathrm{MD}=0.72)$. While the dimensions of lack of readiness only slightly decreased from pretest to posttest $(\mathrm{MD}=0.25)$. Different things happen to the control group. In the control group, 
the score of career decision-making difficulties actually increased from pretest to posttest. The increase is quite large especially in the dimensions of lack of information $(\mathrm{MD}=0.52)$. While the dimensions of lack of readiness $(\mathrm{MD}=0.13)$, inconsistent information ( $\mathrm{MD}=0.17$ ), and total career decision-making difficulties $(\mathrm{MD}=0.27)$ only slightly increased from pretest and posttest.

Table 3.Dimension Description of Difficulty Level of Career Decision-Making

\begin{tabular}{|c|c|c|c|c|c|c|c|c|c|}
\hline & & \multicolumn{4}{|c|}{ Pretest } & \multicolumn{4}{|c|}{ Posttest } \\
\hline & & LoR & LoI & II & Total & LoR & LoI & II & Total \\
\hline \multirow[t]{2}{*}{ Experimental } & Mean & 4.89 & 4.94 & 4.44 & 4.76 & 4.64 & 3.88 & 3.59 & 4.04 \\
\hline & $S D$ & 1.01 & 1.73 & 1.48 & 1.18 & 1.24 & 1.69 & 1.18 & 1.33 \\
\hline \multirow[t]{2}{*}{ Control } & Mean & 4.50 & 3.99 & 3.86 & 4.12 & 4.63 & 4.51 & 4.03 & 4.39 \\
\hline & $S D$ & 1.22 & 1.61 & 1.40 & 1.24 & 1.27 & 1.70 & 1.48 & 1.32 \\
\hline
\end{tabular}

Comparison Test of Pretest and Posttest Results

Table 4.Comparison Test of Pretest and Posttest Data

\begin{tabular}{lcccc}
\hline & \multicolumn{2}{c}{$\boldsymbol{T}$ (sig.) } \\
& LoR & LoI & II & Total of \\
Difficulty
\end{tabular}

Note: LoR =Lack of Readiness; LoI = Lack of Information; II = Inconsistent Information; ${ }^{*} p<$ 0,$05 ; * * p<0,01 ; * * * p<0,001$

Based on the results of comparison test using Paired Sample T-Test, in the experimental group there were significant differences in score of lack of information, inconsistent information, and difficulty of overall career decisionmaking. However, there is no significant difference in readiness level or lack of readiness between before and after manipulation. Referring to the $t$ score and the mean score at the time before and after the experiment is done, it can be said that significant differences occur due to the decrease of difficulty level in career decision-making in the participants.

While in the control group there are also significant differences in the lack of information and the difficulty level of overall career decision-making, but not on the lack of readiness and inconsistent information. However, referring to the $t$ score and the mean score during pretest and posttest, significant differences occur due to an increase in the level of difficulty of career decision-making in participants. Improved scores also occur in other dimensions where there are no significant difference (lack of readiness and inconsistent information).

Overall, it can be concluded that the treatment or manipulation provided during this four-month period is effective in reducing the level of difficulty of decisionmaking (lack of information, inconsistent information, and total difficulties), but less effective in reducing the level of lack of readiness.

\section{Conclusion}

This study aims to determine the effectiveness of career planning programs in Psychology students. This program is conducted in 8 sessions. During the 
intervention process the participants seemed enthusiastic about each activity. The experimental group and the control group were taken from the sample of Psychology students in the same semester, which is the $6^{\text {th }}$ semester. The results of this study indicate that the treatment or manipulation provided during these eight sessions was effective in reducing the difficulty level of career decision making (lack of information, inconsistent information, and total difficulties), but less effective to lower the level of lack of readiness.

Advices for participants and students of the Faculty of Psychology in general, should the students seek a broader perspective on a career that can be occupied in the field of psychology. Furthermore, students can choose some career alternatives that match the potential, interest and value owned by students. Students can obtain information about this career through the internet, discussions with lecturers and with alumni who have worked in areas of interest of the students. Further suggestions for the Faculty or Psychology Study Program, the study program should facilitate students with training related to career-planning like this, so later as graduated from the Faculty of Psychology, the students can make the right career decisions for the future and ready to face the working world. Suggestions for parents, parents should invite their children to discuss this career problem since early stage. Parents as the closest people to the children can be a source of information for children to discuss career issues that match their children's character, potential and interests. However, parents need to be wise in expressing opinions and motivating children to be able to make career decisions independently, so that in the end the child can make the right decision because itis well thought out.

\section{References}

Capuzzi, D. \& Stauffer, M.D. (2006). Career counseling: foundations, perspectives, and applications. Boston: Pearson Education.

Flannery, M.E., (2010). Top eight challenges teachers face this school year. Retrieved on 20 October 2015 from http//www: neatoday.org/2010/09/13.

Gati, I. (2013). Advances in career decision making. In Walsh, W. B. (Ed.), Savickas, M. L. (Ed.), \& Hartung, P (Ed.), Handbook of vocational psychology: Theory, research, and practice. London: Routledge. Retrieved from https://books.google.com/books?isbn=1136500006.

Gati, I., \& Tal, S. (2008). Decision-making models and career guidance. In Athanasou, J. A., \& Van Esbroeck, R (Eds.), International handbook ofcareer guidance (pp. 157-185). Dordrecht: Springer.

Gati, I., Gadassi, R., \& Shemesh, N. (2006). The predictive validity of a computerassisted career decision-making system: A six-year follow- up.Journal of Vocational Behavior, 68(2), 205-219.

Gati, I., Saka, N., \& Krausz, M. (2001). 'Should I use a computer-assisted career guidance system? 'It depends on where your career decision-making difficulties lie. British Journal of Guidance and Counseling, 29(3), 301-321.

Gati, I. \& Asher, I. (2001). The PIC model for career decision making: Prescreening, in-depth exploration, and choice. In Leong, F. T. L., \& Barak, A (Eds.), Contemporary models in vocational psychology: A volume in honor 
of Samuel H. Osipow, (pp. 7-54). Mahwah, NJ: Lawrence Erlbaum Associates Publishers.

Gati, I., \& Asher, I. (2001). Prescreening, In- Depth Exploration, and Choice: From Decision Theory to Career Counseling Practice. The Career Development Quarterly, 50(2), 140-157.

Gati, I., Krausz, M., \& Osipow, S. H. (1996). A taxonomy of difficulties in career decision-making. Journal of Counseling Psychology, 43, 510-526.

Gysbers, N.C., Heppner, M.J., Johnston, J,A. (2009). Career counseling: context, processes, and techniques. Alexandria, VA: American CounselingAssociation.

Imda, A.N. (2016). Efektivitas Pelatihan Model PIC (Prescreening, In-Depth Exploration, Choice) dalam Mereduksi Kesulitan Pengambilan Keputusan Karir pada Remaja. Jakarta: Universitas Tarumanagara. Unpublished thesis.

Isaacson L.E.\& Brown, D. (1993). Career information, career counseling, career development. Needham Heights, Massachusetts: Allyn and Bacon.

Kusmayadi, I. (2011). Membongkar kecerdasan anak: Mendeteksi bakat dan potensi anak sejak dini. Jakarta: Gudang Ilmu.

Lemme, B.H. (2006). Development in adulthood (4 ${ }^{\text {th }}$ ed). Boston: Pearson Education, Inc.

Munandar, S.U. (1997). Strategi pengembangan keberbakatan \& kreativitas. Jakarta: Grassindo.

Niles, S.G. \& Bowlsbey, J.H. (2009). Career development interventions in the $21^{\text {st }}$ century. Upper Saddle River, NJ: Pearson Education.

Pengertian definisi mahasiswa menurut para ahli. (2012). Retrieved from http://definisipengertian.com/2012/pengertian-definisi-mahasiswa-menurutpara-ahli/

Santrock, J.W. (1999). Lifespan development. Boston: Mc.Graw Hill.

Sarafino. (1999). Health psychology. Boston: McGraw - Hill

Walgito, B. (2010). Bimbingan dan konseling: studi dan karier. Yogyakarta: Penerbit ANDI. 